\title{
A crescente onda do veganismo e o surf das FoodTechs
}

\section{The rising wave of veganism and the "surfing" of FoodTechs}

Lígia Moraes de Campos ${ }^{1}$

O vegetarianismo e seu sucessor veganismo vêm ganhando força e espaço gradativo entre dietas contemporâneas.

Em pesquisa do Instituto Brasileiro de Opinião Pública e Estatística (Ibope) de 2012, 8\% da população brasileira se declarou vegetariana. A mesma pesquisa aplicada em 2018 teve resultado nacional de $14 \%$ de população vegetariana. O índice eleva-se a $16 \%$ se consideradas apenas as regiões metropolitanas, com crescimento de $75 \%$ em apenas 6 anos.

$\mathrm{O}$ veganismo também vem crescendo globalmente. Termo derivado da palavra inglesa vegan, pela primeira vez mencionada em 1944 por Donald Watson, na Inglaterra, quando fundou a Vegan Society como defensora de alimentação vegetariana e non-dairy (não láctea) - ou seja, define-se por uma dieta com restrição radical aos alimentos de origem animal, inclusive mel de abelhas ou derivados do leite.

As razões para reduzir o consumo de alimentos de origem animal e com isso adotar uma dieta vegetariana, vegana ou até mesmo a mista flexitariana (onívoros que reduzem o consumo de carne, mas não a eliminam do menu) são de cunhos variados. Com a divulgação global de documentários, livros, organizações ativistas e órgãos defensores dos animais - impulsionada pela velocidade de acesso à informação através das redes sociais -, a população vem tomando consciência do impacto em sua própria saúde, no meio ambiente e na vida dos animais quando escolhem carne para comer. O comensal, comovido de acordo com os seus valores, decide então pela mudança de seus hábitos alimentares ou, no caso dos extremos veganos, até mesmo em seu vestuário e objetos pessoais.

Entretanto, ser vegano - pela sustentabilidade, pelos direitos animais ou até mesmo por uma melhor nutrição - tem seu viés também capitalista. De olho nessa tendência, grandes multinacionais de alimentos adaptam seu portfólio para oferecer ao consumidor versões veganas dos seus produtos. Pequenas empresas surgem com opções plant-based de alimentos. A startup chilena The Not Company, fundada em 2015, com sua versão vegana da maionese que não é maionese, teve crescimento exponencial a ponto de, em 2019, receber um aporte de USD 30 mi vindo de Jeff Bezos, fundador da Amazon. A foodtech Beyond Meat, fundada em 2009 com o propósito de entregar uma proposta vegana de um hambúrguer usando os adventos da tecnologia, abriu oferta pública de ações na bolsa de valores americana Nasdaq em maio de 2019 a USD 45 a cota e já apresentou picos de USD 239 nesses últimos meses.

Comida industrial, vegana ou não, sempre foi "tech". A indústria de alimentos, desde que invadiu os lares no pós-guerra, substituiu o hábito de cozinhar através da tecnologia, produzindo enlatados, congelados e afins. Assim, os ultraprocessados dominaram a alimentação cotidiana, gerando uma verdadeira amnésia referencial gastronômica. Ser vegano e entregar-se às propostas 
tech resolvem a consciência do comensal com respeito aos animais. As consequências sobre sua saúde, no entanto, ainda estão por ser conhecidas. Citando Michael Pollan: "se é planta, coma. Se é feito uma planta, não".

Palavras-chave: veganismo; vegetarianismo; foodtech; ultraprocessados; plant-based.

Keywords: veganism; vegetarianism; foodtech; ultra-processed foods; plant-based.

1 Pós-graduada em Gestão Estratégica de Embalagens na Escola Superior de Propaganda e Marketing. 